\title{
QUANTITATIVE ASSESSMENT OF THE DYNAMICS OF RAIL FREIGHT TRANSPORTATION
}

\author{
Romualdas Ginevičius ${ }^{1}$ and Gintaras Sinkevičius ${ }^{2}$ \\ ${ }^{1)}$ Bialystok University of Technology, Faculty of Management, \\ Department of Business Informatics and Logistics, 15-351 Biatystok, Poland. \\ ${ }^{2)}$ Vilnius Gediminas Technical University, LT-10223 Vilnius, Lithuania.
}

Please cite this article as:

Ginevičius, R. and Sinkevičius, G., 2020. Quantitative Assessment of the Dynamics of Rail Freight Transportation. Amfiteatru Economic, 22(54), Article History

Primit: 15 December 2019

Revizuit: 20 January 2020 pp. 579-591.

Acceptat: 19 March 2020

DOI: $10.24818 / \mathrm{EA} / 2020 / 54 / 579$

\begin{abstract}
Freight transportation by rail is one of the most important factors in the country's economic development; and, therefore, a comprehensive analysis of the business development has both scientific and practical significance. The basis for the analysis and conclusion of this type is a possibility to measure the trends of transport development. They have been objectively reflected in the dynamics of transportation business during the given period. The dynamics has been reflected by two indicators: the level, and the intensity of the transportation operations. The consistency of transportation operations can be determined as the ratio between the size of the time span and the size of the trajectory of the actual development. Whereas the intensity of the shipment can be determined as the ratio between the amount of shipment at the end of the period as compared to the same value at the beginning of the period under consideration. The calculations have shown that there is a fairly strong link between GDP per capita for the country and the dynamics of rail freight transportation.
\end{abstract}

\section{Keywords}

Railway transportation, international markets, dynamics of rail freight transportation, economics, internationalization, sustainable development, intensity of transportation, dynamics of transportation, uniformity of transportation.

JEL Classification: R1, R4, C6

\footnotetext{
${ }^{1}$ Corresponding author, Romualdas Ginevičius - romualdas.ginevicius@ vgtu.lt
} 


\section{Introduction}

Rail transportation (hereinafter referred to as "RT") is one of the major economic drivers of the global and regional development (Christopher 2011; Granger \& Kosmider 2016). This is an important element of the development of technology and international economic relations (Hays 2010; Siciliano et al. 2017). The business of rail transportation significantly influences the processes of globalization, and it is an integral part of internationalization processes (Granger \& Kosmider 2016; Wang et al. 2018). Research of this problem has consistently highlighted the growing importance of RT over the recent time. In particular, it has grown on the basis of global and regional development through the adoption of the concept of sustainable development, which focuses on the ecological issues of human and economic development (WCED 1987).

To start with, rail freight transportation has a direct impact not only on economic performance but also on processes, such as regional development, city urbanization, and alike. (Atack \& Bateman 2006; Islam et al. 2013). It is an integral part of the interaction between the given economic activity and transport links (Wishniewski 2015). Owing to rail transportation, modern processes, such as globalization, technological progress, people's mobility, and trade are developing (Gereffi \& Fernandez-Stark 2011; Newman et al. 2017).

In the region of the Baltic Sea, freight transportation by rail accounts for about 40 per cent of all cargo flows (Ketels \& Pedersen 2016). Their volumes largely depend on the geographic location of the country. The countries of the European Union, which are intercrossed by the international transport corridors are situated in a rather favorable position (Morana et al. 2014; Upadhyay \& Bolia 2014; Summers 2016). These countries, whose territory is bordered by the Eurasian Economic Area, between 2014 and 2015, make 80-95 per cent of all international rail freight flows (Allesandrini et al. 2016; Gherghina et al. 2018). The dynamics of international trade and cargo transportation in the Baltic Sea area is analyzed by the relative distribution of transportation flows to the North-South and EastWest directions (Baltic Sea ... 2014). Table 1 and Figure 1 show that freight transportation by rail has varied considerably between North-South and East-West. In the East-West direction freight flows are about ten times larger than in the North-South direction (Baltic Transport ... 2011). One of the reasons for this discrepancy is that northern export to the southern countries is almost at a twice higher volume than import ( $\mathrm{Li}$ et al. 2017). Meanwhile, the eastern export to the West is much higher than the import.

Table no. 1: The statistics for Freight rail transport for the Baltic Sea Region countries as of 2005-2017, thousand $t$.

\begin{tabular}{lccccccccccc}
\hline \multirow{2}{*}{ Year } & $\mathbf{2 0 0 8}$ & $\mathbf{2 0 0 9}$ & $\mathbf{2 0 1 0}$ & $\mathbf{2 0 1 1}$ & $\mathbf{2 0 1 2}$ & $\mathbf{2 0 1 3}$ & $\mathbf{2 0 1 4}$ & $\mathbf{2 0 1 5}$ & $\mathbf{2 0 1 6}$ & $\mathbf{2 0 1 7}$ \\
\cline { 2 - 11 } Country & \multicolumn{10}{c}{ Freight quantity thous. t } \\
\hline Latvia & 56.061 & 53.679 & 49.164 & 59.385 & 60.601 & 55.831 & 57.039 & 55.645 & 47.819 & 43.785 \\
Lithuania & 54.970 & 42.669 & 48.061 & 52.330 & 49.377 & 48.028 & 49.000 & 48.053 & 47.651 & 52.638 \\
Estonia & 52.752 & 45.954 & 46.705 & 48.378 & 44.725 & 43.682 & 36.289 & 28.026 & 25.364 & 27.256 \\
Finland & 41.937 & 32.860 & 35.795 & 34.827 & 35.267 & 36.433 & 37.008 & 33.392 & 36.162 & 38.406 \\
Sweden & 65.632 & 56.466 & 68.329 & 67.907 & 65.789 & 67.047 & 68.035 & 64.999 & 67.479 & 69.350 \\
Poland & 248.860 & 200.819 & 216.767 & 248.606 & 230.878 & 232.596 & 227.820 & 224.320 & 222.523 & 233.982 \\
Denmark & 7.198 & 6.163 & 8.121 & 9.276 & 7.982 & 7.956 & 8.082 & 8.652 & 9.383 & 9.314 \\
Germany & 371.298 & 312.087 & 355.715 & 374.737 & 366.140 & 373.738 & 365.003 & 367.314 & 363.512 & 348.559 \\
\hline
\end{tabular}

Source: EC 2019. 


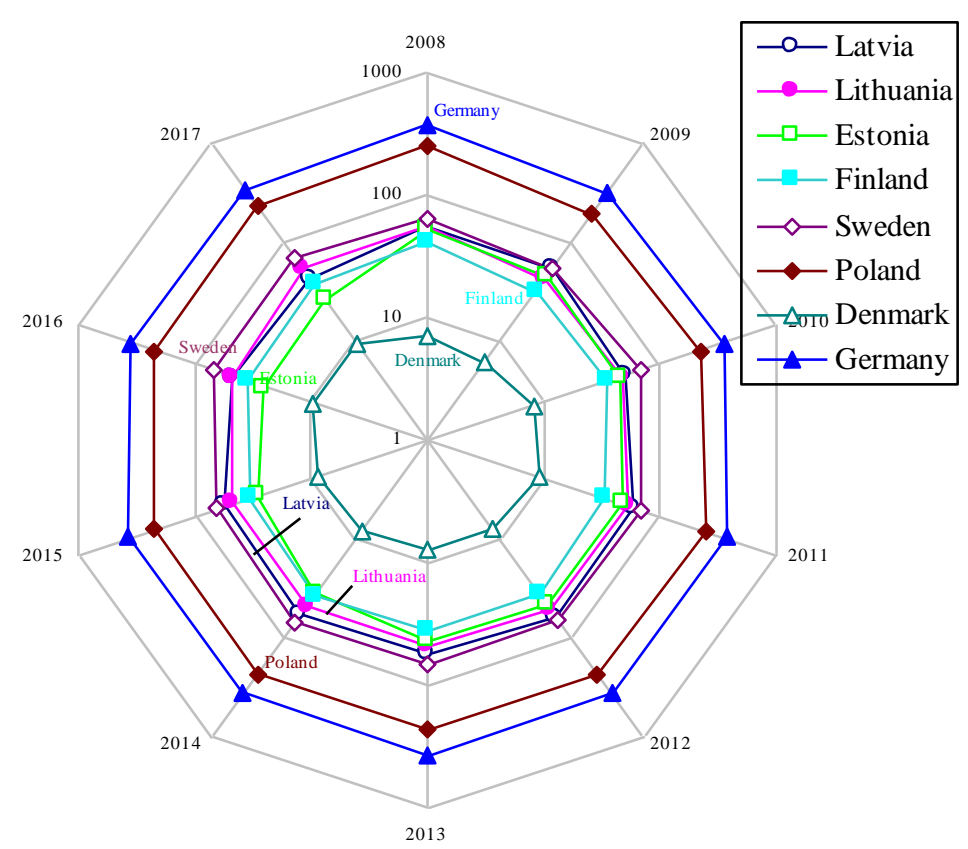

Figure no. 1: Rail freight volumes in the Baltic Sea Region Source: completed by the authors.

In 2014, the International Union of Railways (UIC) developed directions for strategic technical and technological development of European rail transportation, reflecting upon the priorities of the implementation of the RT policy. The priorities also emphasize the sustainable development alongside as consistency, security, reliability, financial efficiency and other components (UIC 2014). Concerning this context, the research on the effectiveness of RT has highlighted the following issues of its development: the lack of a critical approach to the development of rail transportation in modern business conditions; there is a lack of consistent analysis and forecasts of freight transportation by rail that allows targeted integration with other business types (Pitmann 2009; Ruijia et al. 2014). For these reasons, the GCC sector is losing out in a competitive struggle for cargo flows (Makitalo 2010; Steele \& Hodge 2011). Modern approaches to the development of RT are needed, together with new research covering new aspects that have not yet been explored (Sinkevičius \& Dailydka 2014).

Anyway, the basis for this kind of analysis, and research, is the possibility of quantifying the actual state of development of the RT. The objective of the article is to quantitatively evaluate the dynamics of rail freight transportation over the ten-year period in the countries of the Baltic Sea region, and to determine this impact on the country's economic development.

\section{Methodology for quantitative assessment of dynamics of rail freight transportation}

The country's railway system has all the characteristics of socioeconomic systems (SES). It is large, complex, and in reality it manifests itself in a large number of different aspects (Klapita 2012). It is an open system, so it is constantly exposed to the surrounding environment. This environment promotes the need for continuous growth. There is a need 
to enable the system to adapt to the ever-changing external situation. This can only be achieved through continuous development (Alvarez et al. 2009; Chen 2012; Crozet 2017). Cargo transportation is an essential component of the national railway transportation. It is the business that has a major impact on the national economy (Ivaldi \& McCullough 2010; Wang 2012; Cervantes 2013). It is, therefore, important for the science and practice to fully examine the conditions under which the success depends. The basis for such analysis is provided by the ability to quantify the actual status of development at the time point under consideration. The structure of freight transportation by rail can be reflected upon two essential aspects - the intensity of transportation and the consistency (Ginevičius et al. 2018). Their integral size is conveyed by the dynamics of transportation (Figure 2). The dynamics, as an indicator of the state of rail transportation, matters because it marks the evolution of any kind of process, evolution, and course of some kind of phenomenon.

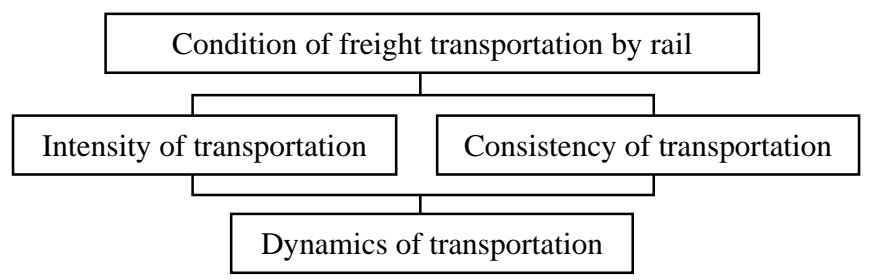

Figure no. 2: The structure of rail freight transportation Source: authored by Ginevičius et al. 2018.

The process of dynamic is characterized by a rapid, tangible development (the European Commission. Eurostat Database ... 2019; the European Commission. The Eurostat statistics ... 2019). The rationale of the parameters of the dynamics - intensity and uniformity - can be confirmed (or denied) by the graphical representation of the actual freight transportation by rail. In order to adequately convey the situation of the countries concerned, the data should be comparable, as the countries differ in size, area, population, etc. This is illustrated by the relative sizes - the volume of freight transported per $100 \mathrm{~km}^{2}$, of the country, the volume of cargo per 1000 of the country's population and so on. Which of these indicators should be taken as a basis for the future research can be reflected in their relationship with the economic development of the countries, which we can express by GDP per capita (Maibach et al. 2008; Liddle \& Lung 2013). The correlation analysis has shown that it would prove to be meaningful to collect the amount of cargo transported per 1000 inhabitants of the country. For the countries concerned, this indicator is presented in Table 2 and Figure 3, where these changes are graphically represented.

Table no. 2: Rail freight volumes per 1000 of the country's population

\begin{tabular}{|c|c|c|c|c|c|c|c|c|c|c|c|}
\hline & $\begin{array}{l}\text { Year } \\
\text { Country }\end{array}$ & 2008 & 2009 & 2010 & 2011 & 2012 & 2013 & 2014 & 2015 & 2016 & 2017 \\
\hline 1 & Latvia & 25.822 & 250251 & & & & 27.3681 & 28.293 & 27.9342 & 24.273 & 22.465 \\
\hline 2 & Lithuania & & & & & & & & & & 18.2138 \\
\hline 3 & Estonia & 39.3 & & & & & & & & & 20.8220 \\
\hline 4 & Finland & 7.8843 & 6.1512 & 6.6719 & 6.4626 & 6.5164 & 6.7021 & 6.7520 & & 713 & 6.9538 \\
\hline 5 & Sweden & 7.106 & 6.18 & 7.2767 & 7.17 & 6.89 & 6.9 & 7.02 & 6.70 & 117 & 6.9979 \\
\hline 6 & Poland & 6.493 & 5.240 & 5.6563 & 6.4876 & 6.02 & 6.0 & 5.9493 & 5.8622 & 5.8215 & 6.1299 \\
\hline 7 & Denmark & $1.30 \mathrm{~s}$ & 1.11 & 1.46 & 1.66 & & & 1.4 & & 1.6429 & 1.6246 \\
\hline 8 & Germany & 4.5765 & 3.8674 & 4.3972 & 4.6302 & 4.5165 & 4.5990 & 4.4791 & 4.4955 & 4.4377 & 4.2448 \\
\hline
\end{tabular}

Source: authors' compilation of rail freight statistics based on Eurostat. 


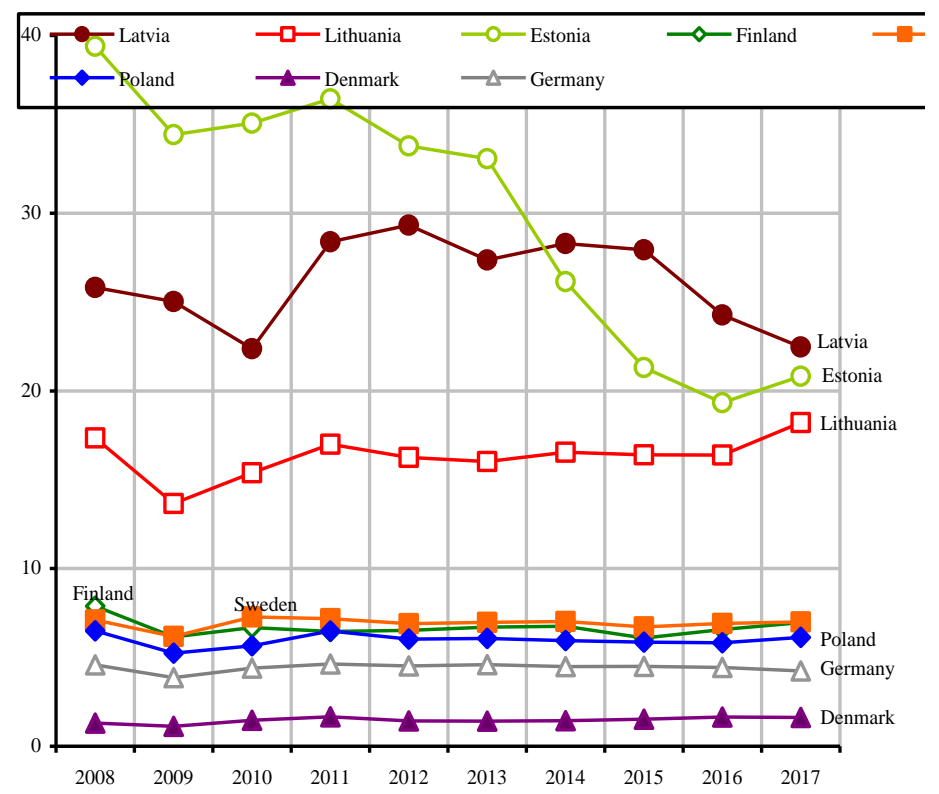

Figure no. 3: Dynamics of rail freight transportation in the Baltic region in 2008-2017

Source: composed by the authors.

Figure 3 shows that, in addition to the two parameters (intensity and uniformity), the duration of the period under consideration should be taken into account, in order to summarize the development of rail freight transportation. The first two parameters for each country will be different, e.g. the first two are variables, and the third one is constant. Figure 3 also shows that whereas transportation intensity increases, the uniformity decreases. Hence, in order to obtain an adequate view of the uniformity of transportation, the condition is that the value should not be affected by the intensity of the carriage. The intensity indicator should accordingly be integrated into the dynamics of transportation development. In this case, the system of indicators for the development of rail freight transportation can be demonstrated as depicted below (Figure 4).

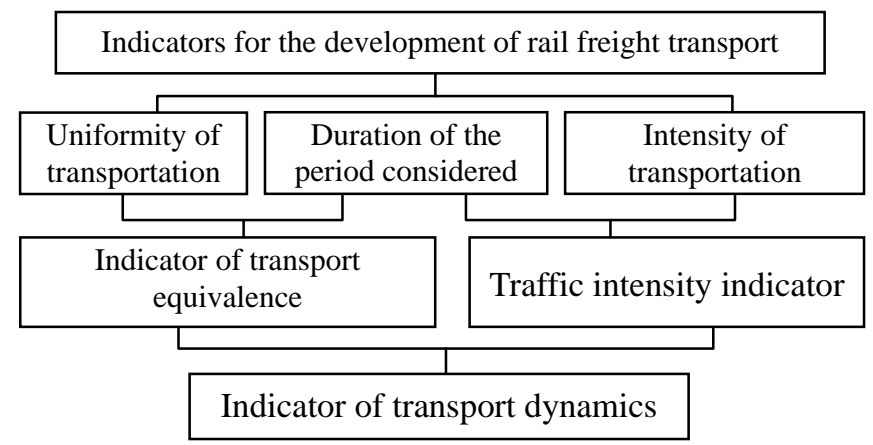

Figure no. 4: The system of indicators for the development of rail freight transportation

Source: composed by the authors. 
Combinations of variable parameters - intensity and uniformity - in the process of development of freight transport by rail transportation allow to distinguish typical situations (Figure 5).

\begin{tabular}{|c|c|c|c|}
\hline & \multicolumn{2}{|c|}{ Rail freight intensity } \\
\hline & & Intensive & Non intensive \\
\hline \multirow{2}{*}{ 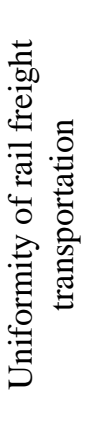 } & 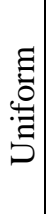 & $\begin{array}{l}\text { Intensive and } \\
\text { uniform (high } \\
\text { degree of } \\
\text { development } \\
\text { dynamics) }\end{array}$ & $\begin{array}{l}\text { Non intensive either } \\
\text { uniform (average } \\
\text { degree of } \\
\text { development } \\
\text { dynamics) }\end{array}$ \\
\hline & 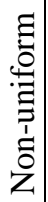 & $\begin{array}{l}\text { Intense, but uneven } \\
\text { (average degree of } \\
\text { development } \\
\text { dynamics) }\end{array}$ & $\begin{array}{l}\text { Intense and uneven } \\
\text { (low dynamics of } \\
\text { development) }\end{array}$ \\
\hline
\end{tabular}

Figure no. 5: Typical cases of the development of rail freight transportation development Source: composed by the authors.

Based on Figure 5, the countries in consideration can be classified as quadrants (Figure 6):

\begin{tabular}{|c|c|c|c|}
\hline & & \multicolumn{2}{|c|}{ Rail freight transportation intensity } \\
\hline & & Intensive & Non intensive \\
\hline \multirow{2}{*}{ 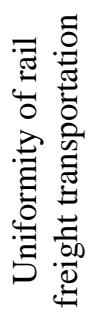 } & हี & $\begin{array}{l}\text { Estonia, } \\
\text { Latvia, } \\
\text { Lithuania }\end{array}$ & $\begin{array}{c}\text { Denmark, Poland, Finland, } \\
\text { Sweden, Germany }\end{array}$ \\
\hline & 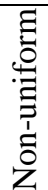 & - & - \\
\hline
\end{tabular}

Figure no. 6: The situation of rail freight in the countries concerned Source: composed by the authors.

The quantification of the transportation of goods by railways will be quantified on the basis of fluctuations in the volume of transportation during the particular periods of the period under review. This can be done on the basis of the difference in the development of transportation times of adjacent periods of time (Ginevičius et al. 2018). Figure 7 shows what the transformed Figure 3 depicts upon transformation. The graphs show the ascending and descending curves accordingly to the countries in question. 


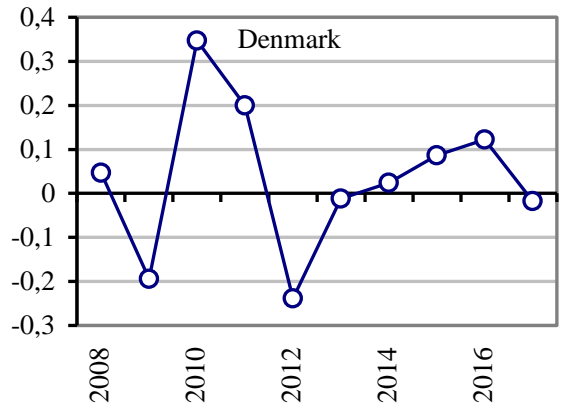

a)

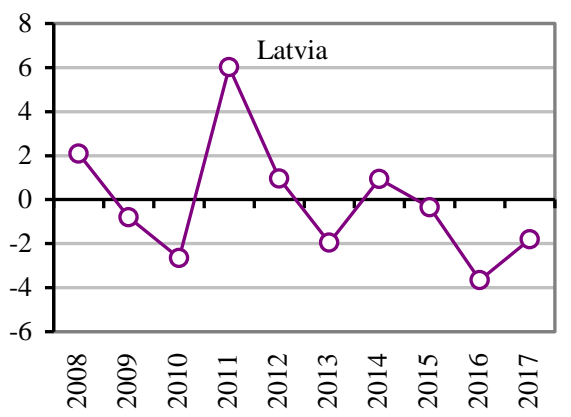

c)

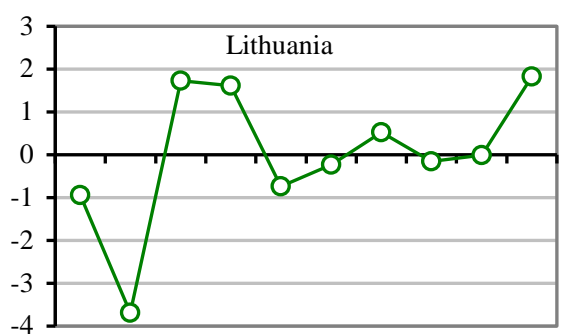

究

e)

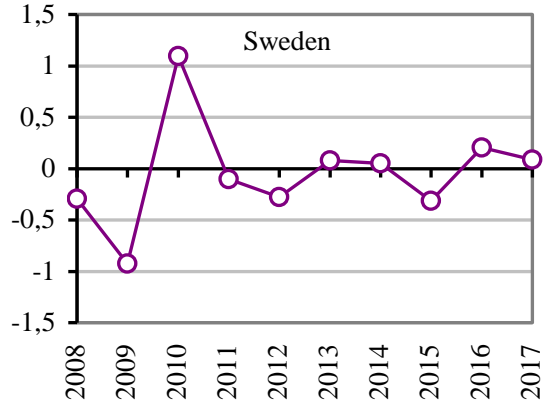

g)

Figure no. 7: Uniformity of rail freight transportation in the Baltic Sea region for 2009-2010: a) Denmark, b) Estonia, c) Latvia, d) Poland, e) Lithuania, f) Finland, g) Sweden, h) Germany

Source: authors' compilation of rail freight statistics based on Eurostat.
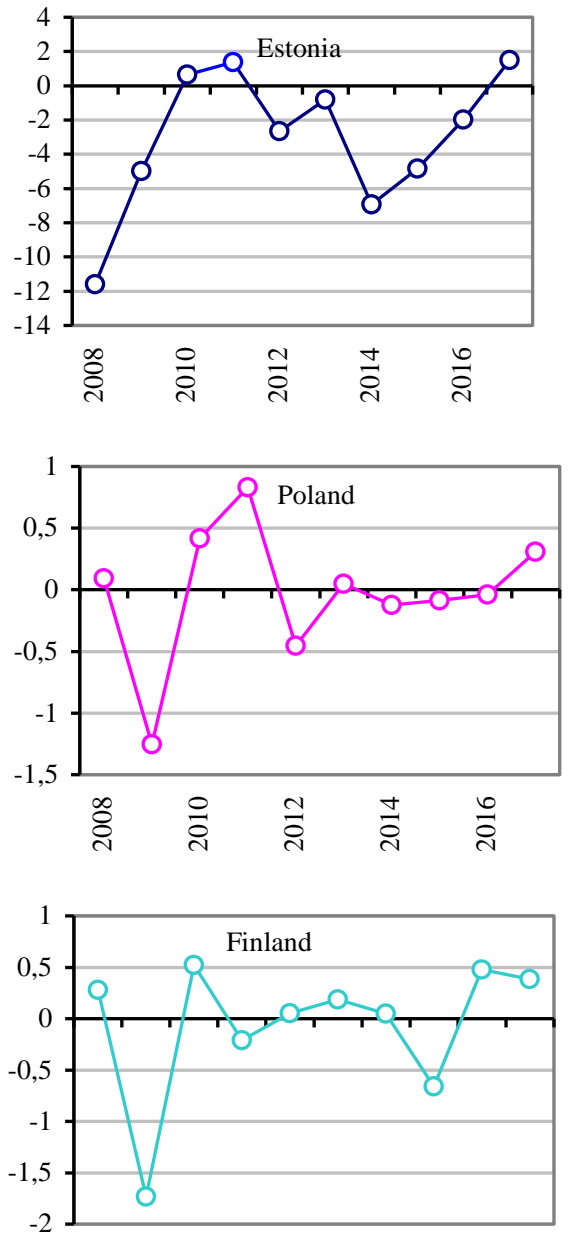

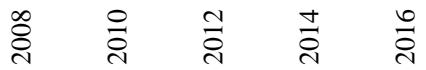

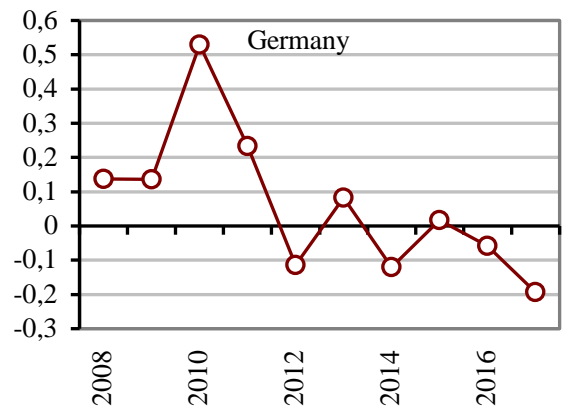


The dynamics of rail freight transportation in the countries of the Baltic Sea Region will be determined based on the MDD method (Ginevičius et al. 2018). The essence of the method is that the uniformity of the development of the examined process is determined first, and then its value is adjusted by the indicator of intensity. The development equilibrium indicator, based on the methodology explained earlier, is calculated as the ratio of the size of a total duration of the analyzed period to a size of the tactical development trajectory. The actual length of the development trajectory is the sum of the growth rates for each time period in relation to the period in question. It is determined on the basis of Figure 7 . Therefore, we now know the significance of the development at the beginning and end of each time period (Figure 8).

From Figure 9 one can notice that during the period under review, the trajectory of the development of transportation in the $i$-th period is reflected by the $P_{i}$ and $P_{i}+1$, the diagonals of the right-angled triangle.

$$
P_{i} P_{i+1}=\sqrt{1+\left(P_{i+1}-P_{i}\right)^{2}}
$$

In this case, the total length of the actual trajectory for the period under consideration is determined as the sum of the lengths of the individual trajectory of the time, and the development equilibrium index $D^{T}$ is as follows:

$$
D^{T}=\frac{N-1}{\sum_{i=1}^{N-1} \sqrt{1+\left(P_{i+1}-P_{i}\right)^{2}}},
$$

where:

$N \quad-$ period under consideration;

$(N-1) \quad$ - number of periods of considered duration by years.

The proposed methodology has been tested to determine the dynamics of rail freight transportation in the Baltic Sea Region countries.

\section{Evaluation of the dynamics of rail freight transportation}

The results of the calculations of uniformity of rail freight transportation development in the Baltic region countries are presented in Table 3 according to the methodology described above.

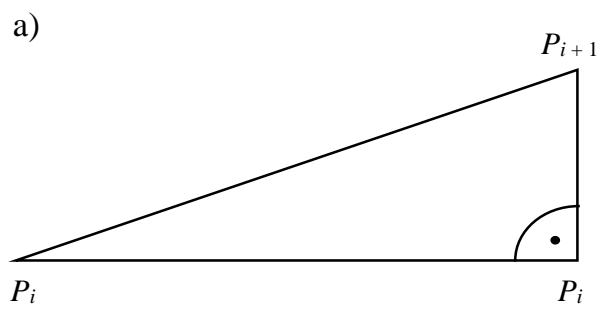

b)

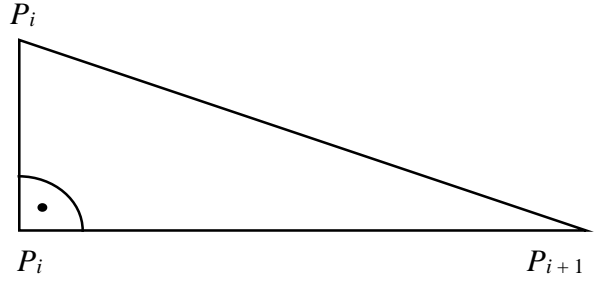

Figure no. 8: Depicting the trajectory of rail freight development $i$-time period (where a-positive development, $b$ - negative development);

$\left(P_{i}-i\right.$ - is the size of the time period of transportation at its beginning;

$P_{i+1}$ the same value, at the end of time period 
Table no. 3: The significance of the development of rail freight transport in the Baltic States

\begin{tabular}{|l|l|l|l|l|l|l|l|l|}
\hline Country & Denmark & Estonia & Latvia & Poland & Lithuania & Finland & Sweden & Germany \\
\hline $\begin{array}{l}\text { Uniformity } \\
\text { indicator } D^{T}\end{array}$ & 0.985 & 0.322 & 0.408 & 0.887 & 0.592 & 0.863 & 0.903 & 0.956 \\
\hline
\end{tabular}

The second indicator of the dynamics of rail freight transportation, namely, the intensity of transport, can be determined as follows:

$D_{j}^{I}=\frac{Q_{j}^{T}}{Q_{j}^{b}}$,

where:

$D_{j}^{I}$ - intensity of rail freight transportation in country $j$,

$Q_{j}^{T}-j-$ the size of the country's transportation at the end of the period under review, and

$Q_{j}^{b}$ - the same value at the beginning of the period under consideration.

Table 4 shows the results of the calculation of the intensity indicator for rail freight development.

As can be seen from Table 4, the development of transportation in all countries except Denmark and Lithuania was negative.

Table no. 4: Indicators of intensity of freight transport development in the Baltic Region Countries in a year 2008-2017

\begin{tabular}{|l|l|l|l|l|l|l|l|l|}
\hline Country & Denmark & Estonia & Latvia & Poland & Lithuania & Finland & Sweden & Germany \\
\hline $\begin{array}{l}\text { Intensity } \\
\text { indicator } D^{I}\end{array}$ & 1.241 & 0.529 & 0.870 & 0.944 & 1.050 & 0.882 & 0.985 & 0.928 \\
\hline
\end{tabular}

Source: comprised by authors.

We will set the indicator of the dynamics of rail freight transportation as a measure of equilibrium $D^{T}$ and intensity indicator $D^{I}$ product:

$D^{D}=D^{T} \cdot D^{I}$.

The results of the calculations are presented in Table 5 .

Table no. 5: The Importance of the rail freight transportation dynamics indicator for the Baltic Countries during 2008-2017

\begin{tabular}{lllllllll}
\hline Country & Denmark & Estonia & Latvia & Poland & Lithuania & Finland & Sweden & Germany \\
\hline $\begin{array}{l}\text { Dynamics } \\
\text { indicator } D^{D}\end{array}$ & 1.222 & 0.170 & 0.355 & 0.837 & 0.622 & 0.761 & 0.899 & 0.887 \\
\hline \multicolumn{8}{c}{ Source: compiled by the authors. } \\
\hline \multicolumn{8}{c}{ : comple }
\end{tabular}

The objective of analyzing the dynamics of rail freight transportation can also be applied to compared countries. In this case, we will determine the traffic intensity indicator for the $j$ country:

$\tilde{D}_{j}^{I}=\frac{Q_{j}^{f}}{Q_{b}^{\min }}$ 
where:

$\widetilde{D}_{j}^{I} \quad j$-comparative indicator of the intensity of $j$ country transportation;

$Q_{b}^{\min } \quad-$ the value of shipments at the beginning of the period in question for the country where the value was the lowest.

The integrated dynamics will be set as the $j$-th equilibrium index for the country $D_{j}^{T}$ and intensity indicator $\widetilde{D}_{j}^{I}$ product:

$D_{j}^{D}=D_{j}^{T} \cdot \widetilde{D}_{j}^{I}$

The results of the calculations for the countries concerned are presented in Table 6.

Table no. 6: Comparison of dynamics of freight transportation by rail during 2008-2017 between the Baltic countries (reference point - Danish freight rates for 2008-2017)

\begin{tabular}{|l|c|c|c|c|c|c|}
\hline \multirow{2}{*}{ Country } & \multicolumn{2}{|c|}{$\begin{array}{c}\text { Uniformity indicator of } \\
\text { transport }\end{array}$} & \multicolumn{2}{c|}{$\begin{array}{c}\text { Intensity indicator of } \\
\text { transport }\end{array}$} & \multicolumn{2}{c|}{$\begin{array}{c}\text { Dynamics indicator of } \\
\text { transport }\end{array}$} \\
\cline { 2 - 7 } & Value & Place & Value & Place & Value & Place \\
\hline Denmark & 0.985 & 1 & 1.0 & 8 & 0.985 & 8 \\
\hline Estonia & 0.322 & 8 & 15.902 & 2 & 5.120 & 6 \\
\hline Latvia & 0.408 & 7 & 17.157 & 1 & 7.009 & 2 \\
\hline Poland & 0.887 & 4 & 4.681 & 6 & 4.152 & 5 \\
\hline Lithuania & 0.592 & 6 & 13.910 & 3 & 8.235 & 1 \\
\hline Finland & 0.863 & 5 & 5.311 & 5 & 4.583 & 4 \\
\hline Sweden & 0.903 & 3 & 5.344 & 4 & 4.825 & 3 \\
\hline Germany & 0.956 & 2 & 3.242 & 7 & 13.099 & 7 \\
\hline
\end{tabular}

For further development of rail freight transportation, it is important to determine the relationship between the dynamics of transportation and the indicators that reflect the country's development. In most cases, this indicator is taken as the gross domestic product per capita. This relationship has been established on the basis of correlation-regression analysis. The correlation coefficient between the dynamics of rail freight transportation and GDP has been found to be greater than 0.8 .

\section{Conclusions}

1. Freight transportation by railways is one of the most important factors contributing not only to the economic development of the country, but also to related processes, such as regional social, ecological development, city urbanization and so on. Further development of rail freight transport requires new research, covering aspects that are not yet widely considered. One of these is the search for opportunities to quantify the actual state of development and trends. This trend is adequately reflected in the dynamics of rail freight transport.

2. The dynamics of freight transportation by rail has been reflected upon two indicators: the uniformity and intensity of transportation. The uniformity of transportation can be defined as the ratio between the size of the length of the period considered and the size of 
the actual development trajectory. The intensity of the shipments can be determined as the ratio of the size of the carriage at the end of the period in question to that of the beginning of the period considered.

3. Calculations have shown that all the countries concerned, with the exception of Denmark, are characterized by a negative development of freight transport by RT. This is due to the fact that the high degree of transportation uniformity is outweighed by the decreasing intensity. From this fact it can be concluded that freight transportation by rail is losing competition among the other modes of transportation.

4. Correlation-regression analysis has shown that there is a fairly strong correlation between the countries' Gross Domestic Product per capita, e.g., an indicator of the dynamics of the country's economic development and freight transportation by rail.

\section{References}

Alessandrini, A., Delle Site, P., Filippi, F., Salucci, M. V., 2012. Using rail to make urban freight distribution more sustainable, European Transport/Trasporti Europei 50, pp. 1-17.

Alvarez, I., Marin, R., Fonria, 2009. The role of networking in the competitiveness of firms, Technological Force-casting and Social change 79, pp. 410-421.

Attack, J., Bateman, F., 2006. The Regional Diffusion and adoption of the Steam Engine in American Manufacturing, Journal of Economic History 40, pp. 281-308.

Baltic Sea Region Transgovernance study report - 2014. Blekinge, Sweden, 2014.

Baltic Transport Outlook 2030, Executive Report - final version, December 2011, online [www.baltictransportoutlook.eu/BTO2030_Executive_Report_Final_15-12-2011_new.pdf].

Cervantes, F. P., 2013. Railroads and Economic Growth: A Trade Policy Approach. University of Chicago Mimeo.

Chen, F., 2012. Research on the market share of freight transportation, Railway Operation Technology 18, pp. 24-27.

Christopher, M., 2011. Logistics and supply chain management. Pearson Education Limited, Harlow.

Crozet, Y., 2017. Rail freight development in Europe: how to deal with a doubly-imperfect competition? Transportation Reasearch Procedia 25, pp. 425-442. https://doi.org/10.1016/ j.trpro.2017.05.420.

EC, 2017. Statistics. EU trade flows inside \& outside Europe. [online]. Available at: http://exporthelp.europa.eu/ [Accessed 21 February, 2019].

European Commission. Eurostat Database 2019. Available online: https://ec.europa.eu/ eurostat/data/ database (accessed on 19 January 2019).

European Commission. Eurostat statistic explained 2019. Freight transportation statistics. Available online: https://ec.europa.eu/eurostat/statistics-explained/index.php/Freight_ transport_statistics (accessed on 20 February 2019).

Gereffi, G., Fernandez-Stark, K., 2011. Global Value chain analysis: A primer. Center on globalization, governance and competitiveness $(C G G C)$. North Carolina, USA. 
Gherghina, S. C., Onofrei, M., Vintila, G., Armeanu, D. S., 2018. Empirical Evidence from EU-28 Countries on Resilient Transport Infrastructure Systems and Sustainable Economic Growth. Sustainability 2018, 10, 2900.

Ginevičius, R., Gedvilaitè, D., Stasiukynas, A., Šliogerienè, I., 2018. Quantitative assessment of the dynamics of the economic development of socioeconomic systems based on the MDD method, Inžinerinè ekonomika - Engineering economics, pp. 264-271.

Granger, R. J., Kosmider, T., 2016. Towards a better European transport system, Transportation Research Procedia 14, pp. 4080-4084. https://doi.org/10.1016/j.trpro.2016.05. 505.

Hays, J., 2010. Globalisation and the New politics of Embeded Liberalism. Oxsford: Oxsford Inversity Press.

Islam, D. Z., Zunder, T., Jackson, R., Nesterova, N., Burgess, A., 2013. The potential of alternative rail freight transport corridors between Central Europe and China, Transport Problems 8(4), pp. 45-57.

Ivaldi, M., McCullough, G. J., 2010. Density and integration effects on class I U.S. freight railroads, Journal of Regulatory Economics 19, pp. 161-182.

Ketels, C., Pedersen, H. J., 2016. State of the region report; The Top of Europe - Doing Well Today, Feeling Worried about Tomorrow. Baltic Development Forum, [pdf]. Available at: https://www.bdforum.org/wp-content/ uploads/ 2016/11/2016_RegionRep.pdf.

Klapita, V., 2012. Modeling of intermodal transport chains in selected transport relations, Railway transport and logistic, scientific and technical on-line journal 8(2), pp. 39-46. University of Žilina. ISSN 1336-7943.

Li, J., Wen, J. X., Jiang, B., 2017. Spatial spillover effects of transport infrastructure in Chinese new silk road economic belt, Int. J. E-Navig. Marit. Econ. 6, pp. 1-8.

Liddle, B., Lung, S., 2013. The long-run causal relationship between transport energy consumption and GDP: Evidence from heterogeneous panel methods robust to crosssectional dependence, Econ. Lett. 121, pp. 524-527.

Maibach, M., Schreyer, C., Sutter, D., van Essen, H. P., Boon, B. H., Smokers, R., Schroten A., Doll, C., Pawlowska, B., Bak, M., 2008. Handbook on estimation of external costs in the transport sector produced within the study Internationalisation Measures and Policies for All external Cost of Transport (IMPACT). Delft, February.

Makitalo, M., 2010. Finland - Russia rail transport deregulation future scenarios of market development, International Journal of Shipping and Transport Logistics, pp. 23-27.

Morana, J., Gonzalez-Feliu, J., Semet, F., 2014. Urban Consolidation and logistics Pooling. Springer, Hedelberg, pp. 187-210.

Newman, P., Davies-Slate, S., Jones, E., 2017. The entrepreneur rail model: Funding urban rail through majority private investment in urban regeneration, Research in Transportation Economics, available online: http://dx.doi.org/10.1016/j.retrec.2017.04. 005, last visit: 2019.02.23. 
Pitmann, R. W., 2009. Railway Mergers and Railway Alliances: Competition Issues and Lessons for Other Network Industries. U.S. Department of Justice - Economic Analysis Group; New Economic School (NES).

Ruijia, S., Zhimin, H., Yangfan Z., Penglei, L., 2014. Research on Railway Freight Market Share Based on the Whole Process of Transport. The 9th International Conference on Traffic \& Transportation Studies (ICTTS'2014). Procedia - Social and Behavioral Sciences 138(4): 298-304.

Siciliano, G., Barontini, F., Islam, D. M. Z., Zunder, T. H. et al., 2016. Adapted cost-benefit analysis methodology for innovative railway services. Eur Transp Res Rev (2017).

Sinkevičius, G., Dailydka, S., 2014. Railway transport in the conditions of globalisation. The 8th international scientific conference "Business and Management 2014": selected papers. May 15-16, 2014. Vilnius: Technika, 2014. ISBN: 9786094576522, p. 442-451.

Steele, Ch. W., Hodge, D., 2011. Background Research material for freight facility location selection: A guide for public officials (NCFRP Report 13) National Cooperative Freight Research Program.

Summers, T., 2016. China's 'New Silk Roads': sub-national regions and networks of global political economy, Third World Quarterly 37(9): 1628-1643.

UIC. International Union of Railways. Challenge 2050. The rail sector vision. 2014. Paris.

Upadhyay, A., Bolia, N., 2014. Combined empty and loaded train scheduling for dedicated freight railway corridors, Comput Ind Eng 76: 23-31.

Wang, J., 2012. The Research on Efficiency and Effectiveness of Railway Transport. IERI Procedia 3: 126-130. ISSN 2212-6678, https://doi.org/10.1016/j.ieri.2012.09.021.

Wang, L., Xue, X., Zhao, Z., Wang, Z., 2018. The Impacts of Transportation Infrastructure on Sustainable Development: Emerging Trends and Challenges, Int. J. Environ. Res. Public Health 15: 1172.

WCED. 1987. Available at: http://www.un-documents.net/our-common-future.post

Wishniewski, S., 2015. The Baltic-Adriatic Transport Corridors - Natural Environment of Logistics Infrastructure Development on the Polish Baltic Sea Coast. Logistics and Transport No 1(25)/2015. 